Revue Française de Civilisation Britannique

\title{
A Tale of Female Liberation? The Long Shadow of De-Professionalization on the Lives of Post-War Women
}

Une génération libérée? L'ombre portée de la dé-professionnalisation sur la vie des femmes de la génération d'après-guerre

Eve Worth

\section{OpenEdition}

\section{Journals}

Electronic version

URL: http://journals.openedition.org/rfcb/1778

DOI: $10.4000 /$ rfcb. 1778

ISSN: 2429-4373

\section{Publisher}

CRECIB - Centre de recherche et d'études en civilisation britannique

\section{Electronic reference}

Eve Worth, «A Tale of Female Liberation? The Long Shadow of De-Professionalization on the Lives of Post-War Women », Revue Française de Civilisation Britannique [Online], XXIII-1 | 2018, Online since 20 March 2018, connection on 10 December 2020. URL : http://journals.openedition.org/rfcb/1778 ; DOI : https://doi.org/10.4000/rfcb.1778

This text was automatically generated on 10 December 2020.

\section{c) (i) $९$}

Revue française de civilisation britannique est mis à disposition selon les termes de la licence Creative Commons Attribution - Pas d'Utilisation Commerciale - Pas de Modification 4.0 International. 


\title{
A Tale of Female Liberation? The Long Shadow of De- Professionalization on the Lives of Post-War Women
}

\author{
Une génération libérée? L'ombre portée de la dé-professionnalisation sur la vie \\ des femmes de la génération d'après-guerre
}

Eve Worth

1 Lynn Abrams has adeptly argued that women born around the 1940s in Britain grew up during a period of social change which "rewarded achievement and self-development through education and work rather than marriage and motherhood". ${ }^{1}$ She concluded that as a result of these changes women experienced a "liberation" of the female self and a progressive journey away from "a model of womanhood represented by the service and selfsacrifice of their mother's generation". ${ }^{2}$ This article seeks to build on and complicate this narrative by arguing that although women did experience expanded opportunities in the post-war decades, these opportunities were primarily in gender segregated jobs within the welfare state which were hit hard by the depreciation in working-conditions that occurred from the late 1980s onwards. Women of this generation's material circumstances and sense of self were significantly affected by this reduction in conditions; in part, precisely because they had been socialized to expect more from their working-lives. By foregrounding female experience, the article also aims to demonstrate that the shifts in public sector employment engendered by Conservative governments constituted a process of de-professionalization which principally impacted women workers. This challenges the masculinised narratives of work which dominate the historiography of late twentieth-century Britain. ${ }^{3}$

This article draws on thirty open-ended life history interviews conducted with women born in Britain between 1938 and 1952 with a view to analysing the ways in which their lives interacted with broader political change. In analysing these interviews, the theme of these women's relationship to the welfare state emerged as an important framework 
throughout their lives. On average the interviews lasted about two hours. They began with the question "where were you born?" and covered up to present day, an approach advocated by feminist oral historians such as Abrams. ${ }^{4}$ In order to let the themes emerge more naturally in the course of the research, criteria for recruitment was fairly broad; limited only by gender and birthdate. Methods of recruitment were varied but included: adverts in local newsletters, emails to institutions and attendance at community centre events. There was also to some extent a snowball effect amongst interviewees, defined by Angela Davis as "where each respondent gives the name of another person to participate" a method which especially helps "to secure trust". ${ }^{5}$ As a result of this snowball effect, half of the interviewees are resident in Sheffield which has been a relatively neglected city in terms of oral history, with historians preferring to focus on the north-west of England or Scotland. ${ }^{6}$ The other fifteen interviewees are more scattered; residing in urban centres across England including London, Bristol and Birmingham.

3 The interviewees hail from a variety of class backgrounds: two-thirds self-defined as working-class during childhood, one-sixth clearly described themselves as middle-class and the final one-sixth saw their family as on the cusp of working-class and middleclass. By the time of our interviews around half had experienced social mobility across the life course, primarily upwards from manual working-class to lower professional middle-class. Working for the welfare state often functioned as the main instrument of this social mobility and all but one of the women I interviewed were employed by the state in some form for at least part of their careers even though this was not a criterion of participation in the project. We know very little about the lives of women of this generation beyond the mid-1970s, in part due to the 1968 activism paradigm which directs the historiography. ${ }^{7}$ Despite the life course approach, analysis of oral history can often privilege memories of youth and early adulthood. Therefore, interviews with women born around the 1940s are primarily used to illuminate the 1950s and 1960s; this has led Wendy Webster to describe oral history as "a potentially ageist project". ${ }^{8}$ Taking analysis of the interviews forward in time allows us to consider the impact on women of the profound social and political change that occurred in Britain as social democracy began to falter.

A Conservative government, led by Margaret Thatcher, was re-elected for a third term in 1987. This victory empowered her government to enact a sweeping programme of welfare state reform which was previously feared too radical. Whilst public support for the principle of a welfare state remained high, the government was able to harness " growing dissatisfaction with state services that gave little choice to their users, in which the professional view remained dominant and the parent or patient in waiting-room seemed to count for little". ${ }^{9}$ Particularly important for the purposes of this article was the 1988 Education Reform Act, which historians agree was the most substantial change since the 1944 Education Act, ${ }^{10}$ and the 1990 National Health Service and Community Care Act which constituted the first phase of "the most significant review of the NHS in its 40 year history" (and also affected all welfare professions which came into contact with the health service).$^{11}$ There were also further reforms during John Major's government, including the 1992 Further and Higher Education Reform Act. ${ }^{12}$ This wave of reform deliberately sought to introduce neoliberal principles into the welfare state. Wendy Brown argues that a fundamental aspect of neoliberalism is the "economization' of heretofore noneconomic spheres and practices, a process of remaking the knowledge, form, content and conduct appropriate to these spheres and practices". ${ }^{13}$ The logic of the market was now 
explicitly intended to govern the functioning of welfare institutions. The Working for Patients white paper published in 1989 for example stated that "health authorities [should] become more business-like in their provision of services and the use of resources". ${ }^{14}$ The impact of these policy changes has thus far largely been considered from the perspective of users of these services, ${ }^{15}$ but here the perspective has been reoriented to focus on workers.

5 I argue that as a result of the changes, workers experienced a rapid period of deprofessionalization from 1987 to the late-1990s (which was not reversed by the election of a New Labour government in 1997). ${ }^{16}$ The process of de-professionalization and its key features can be identified from my oral history interviews: it involved the devaluation of professional expertise by politicians, the introduction of a culture of managerialism (with an attendant shift in priorities for resource allocation), and a loss of autonomy in the workplace. These interrelated changes undermine the features of a professional career outlined by Harold Perkin in his seminal work on professional society: "specialized occupations, selected by merit and based on trained expertise", "salaried with benefits"(hence more scope to decide how their time was spent) and "secure" ${ }^{17}$ Just as Perkin argued that professionalization is not an autonomous process but rather driven by changes in social and political culture, ${ }^{18}$ we should understand deprofessionalization as a deliberate consequence of successive Conservative governments' efforts to re-shape the welfare state guided by neoliberal principles.

The article firstly provides a brief overview of why it is so important to centre women in the discussion of welfare state de-professionalization. It then considers each of the three aspects of de-professionalization in turn. Finally, it examines the impact of deprofessionalization on women's social status.

\section{Women Working in the Welfare State}

7 The post-war expansion of the welfare state caused structural change in British society that opened-up new educational and occupational opportunities for women of this generation. A 1980 report produced by Richard Parry, showed that there was a 1.8 million increase in public sector employees in the decade from 1966-76 which meant almost one-third of workers were now employed by the state. The percentage of the public sector workforce that was female rose from 24 per cent in 1951 to 44 per cent in 1976 which "reflects decline in male-dominated nationalised industries and the growth in education and health, which employ over twice as many women as men". ${ }^{19}$ Alongside this, there was also an expansion in local government which administered a significant proportion of welfare services (including education) during the post-war period. Parry stated that the 1970s had witnessed the creation of a "new public sector" which was " increasingly female [and] qualified". ${ }^{20} \mathrm{He}$ concluded that this change had "major social and political implications". ${ }^{21}$

8 There were limited opportunities for women's advancement elsewhere, and parents and schools encouraged young women's entrance into what have been called the "semiprofessions" or the "caring professions"; particularly nursing and teaching (primarily in schools, but also in further education colleges or polytechnics) but also newly invented welfare occupations..$^{22}$ Jean (b.1950) had not especially wanted to be a nurse (her dreams to be a doctor had been met with derision by her grammar school) but she did feel that nursing had "a high status in society" when she entered training in the late 
1960s. ${ }^{23}$ Contemporary studies found that there was a "broader social basis of recruitment" to these professions in the post-war years than during the interwar period. ${ }^{24}$ Sylvia (b. 1945), from a manual working-class background who became a lecturer in a polytechnic, powerfully described that "it was through gaining qualifications and working in education that I gained both access to a much better economic standard of living than that of my parents and to the cultural activities of the dominant class". ${ }^{25}$ This was in large part possible because men flocked to fast-growing, better-remunerated employment in the existing 'senior' professions or in new private sector roles. ${ }^{26}$ The state expansion also necessitated an increase in support roles which were dominated by women. Five of the women in my sample had worked in public sector clerical jobs. This article focuses primarily on the women working in professional capacities, but also uses the narratives of these clerical workers to show that de-professionalization produced a ripple effect in the public sector which altered the conditions of the administrative staff.

Second wave feminists were ambivalent about the impact of the welfare state on women's lives. During the 1970s and early 1980s they wrote a spate of critiques which sought to demonstrate "the discriminatory character of welfare programs and their function to reinforce sexist arrangements in domestic and public life" ${ }^{27}$ The Beveridge Report (1942) was considered the original sin in this regard, enshrining ideas about women's role in society and the family through the way it chose to administer services and benefits. ${ }^{28}$ Feminist scholars paid less attention to women as workers for the state but did note that women were often concentrated in the lower paid roles and that certain welfare professions, such as social worker, could make women complicit in the policing of other women's behaviour. ${ }^{29}$

Nevertheless, women's employment in the public sector overtook men's after 1979. ${ }^{30}$ This trend intersected with the onset of neoliberal policies and occurred when women born around the 1940s were in the midst of their careers. It is notable that post-1987 “ the education and medical professions were a prime and deliberate focus for public displays of government contempt". ${ }^{31}$ Already by the early 1990 s, sociologists were recognising that the power of welfare state professions dominated by female workers had been eroded further than those dominated by males..$^{32}$ The so-called semi-professions experienced the brunt of the changes during the early period of reform. As Anne Phillips and Barbara Taylor have argued, in a patriarchal society "the work of women is deemed inferior simply because it is women who do it...far from being an objective economic fact, skill is often an ideological category imposed on certain work" ${ }^{33}$ It is unsurprising therefore that when the public sector became dominated by women on a macro level its status began to be undermined, and that the first targets would be areas with majority female workers.

\section{Expertise}

The first aspect of the move towards de-professionalization in the late 1980s was a shift away from political elites valuing the expertise of welfare state professionals. The Conservative government sought to review and restructure the health and education systems, but deliberately chose not to seek the views of professionals in order to do so. They not only expressed disdain for an expansive welfare state but also for the professionals who worked for it. Thatcher expounded her belief that they are "powerful interest groups" who aim to disguise their self-interest as "high-minded commitment to some greater good". ${ }^{34}$ She also found them insufficiently "cost-conscious" and slow to 
respond to market forces: ${ }^{35}$ anathema to her neoliberal principles. Rodney Lowe has explained that "any claim [professionals] had to expertise or altruism...was thrust aside. Doctors and teachers alike were excluded from the major reviews of health and education...so too was academia which was denied its accustomed privileged access via royal commissions to policy-making". ${ }^{36}$

Women working in these areas of the welfare state certainly felt that big changes in the structure of their professions were being imposed by the state without much consultation. Elizabeth (b.1940), a doctor, exemplified these sentiments when asked her views on politics: "I just feel politics is interference. I think if you're a professional especially in the medical world it's just crazy. They downward manage teaching and medicine". ${ }^{37}$ Sandra's (b.1946) thoughts on the reorganization of the NHS in the late 1980s and early 1990s demonstrate workers' frustrations. Having trained as a nurse in the late 1960s, by the 1980s Sandra had worked her way up to a position which she enjoyed in a regional health authority. She described this coming to an end when "Thatcher and her cohort decided they didn't want as many regional health authorities and made us all redundant". ${ }^{38}$ Notably, although she did not agree with the decision to get rid of regional health authorities, she did believe there was significant scope for change in the system. This pattern was reflected in other interviews; the women did not disagree with change per se- "we needed to shake things up"39- but specifically with the choices made by the government. Sandra offered a very detailed alternative to the choices made in the reorganization and also noted that she had tried to raise concerns at the time but was made to feel "naughty". ${ }^{40}$

There was also a clear sense expressed by interviewees that the interference by the state was ill-thought through, and ultimately more concerned with political priorities than public service provision. One woman referenced the "inappropriate short termism" of the changes, ${ }^{41}$ and others noted that the Thatcher era settled little but instead ushered in a period of almost continual reform in the welfare state. ${ }^{42}$ Personal testimonies collected by the social research organisation Mass Observation echo these views. Alice (b.1950), a secondary school teacher, wrote that "every education initiative since the days of Thatcher seems to have been introduced without any thought about its ultimate effect" ${ }^{43}$ The Conservative government wanted "preparation for working life" to be the principal aim of the education system ${ }^{44}$ but teachers do not agree that this can be a workable end in itself. Alice elaborated:

14 If I had any say in the matter, (which of course I don't because the government never consults teachers except those who have left the profession often because they couldn't do the job in the first place), I'd try to revive the principle of education for education's sake...the government talks about its great achievements in 'improving education' through targets but it's complete nonsense. All that's happened is that teachers have learned to adapt their methods in order to fit the targets and test. ${ }^{45}$

15 This exclusion of welfare professionals from decision-making was in stark contrast with the mid-century when "faith in the beneficent, public-minded expert underlay the creation of the modern welfare state". ${ }^{46}$ As Paul Wilding has noted a "welfare state is a professional state " and requires professionals' knowledge to function well. ${ }^{47}$ Throughout the post-war years there was an increasing cachet to expertise and professionalism in the public sphere and construction of identities. ${ }^{48}$ It was therefore undoubtedly frustrating for women of this generation (many of whom hailed from working-class backgrounds) that 
just as they had gained professional status and expertise through working for the welfare state these characteristics began to be denigrated by politicians.

In tandem to expertise required by the welfare state in the post-war years, there was also the growth of a certain type of technocratic expertise associated with new careers (largely in corporate industry); which Frank Mort strongly linked to a form of lower middle-class masculinity. ${ }^{49}$ The qualities that were expected from these "organization men" were "complete neutrality in decision-making...and the ability to act, as Max Weber put it, without regard to persons". ${ }^{50}$ It was this type of Weberian "detached and objective expert" ${ }^{51}$ making supposedly rational not emotional decisions that chimed far more with the neoliberal, Thatcherite world view. ${ }^{52}$ We actively see this type of expertise being imported into the welfare state. An example of this is the decision to get the newlyfounded Audit Commission (note the terminology of accounting and finance) to audit the NHS, and the government expressed this explicitly in terms of the commission having the "expertise [to] look at the professional aspects of the [health] service". ${ }^{33}$ In addition, the Better Schools white paper which laid the foundations for the 1988 Education Act stated the value of "prospective teachers having had previous employment...it is particularly helpful for teachers to gain some experience in industry or commerce". ${ }^{54}$

\section{Managerialism}

The introduction of a culture of managerialism into welfare state institutions was a central pillar of the reorganisations and hence of the process of de-professionalization. Managers were considered an important mechanism for ensuring the dissemination of technocratic expertise and compliance amongst staff with the reform agenda. " Strengthening management" in welfare institutions was outlined as one of the government's key reform principles. They wanted both more layers of management and certain positions- such as that of head teacher- to be reconceptualised as management..$^{55}$ Margaret Cook (b.1944) a hospital consultant noted in her autobiography, "the number of managers, and the cost of managing, rose exponentially". ${ }^{56}$ Managerialism illustrates that the state did not straightforwardly contract, but instead priorities altered; in fact, overall social expenditure increased year-on-year in real terms between 1987 and 1996 (with the sole exception of 1988/89). ${ }^{57}$ The government openly vaunted that "the salaries for [new chief executive posts] will be set significantly higher" than existing posts in the NHS "so as to be attractive to good quality managers from both inside and outside". ${ }^{58}$ Thus, unlike in previous years, this new wave of managers were not all promoted from within the profession..$^{59}$ This distinction was noted by Lois (b.1947) in her description of her new manager in the local government arts department: "she was a new breed-a young administrator not your traditional curator type". ${ }^{60}$ She felt this exacerbated how humiliating it was when she was forced to re-apply for her own job during restructuring and was interviewed by this manager.

Managers across the welfare state were tasked with allocating front-line resources in a manner which would exact more from workers for less. Employees felt that "it was perfectly clear what the new priority was amongst the hierarchy of general managers: money and savings" ${ }^{61}$ Barbara (b.1941), who had worked as an administrator at various tertiary education institutions throughout her career, echoed this point. She recalled that "in 1989 higher education was changing". ${ }^{62}$ From then onwards university management: 

in that I might have to take work home or I would stay on and work in my lunchtime... they were always looking to where they could save money...we weren't getting things churned out quickly enough for them, we didn't have the person power. ${ }^{63}$ home life, and between work time and break time, was mentioned frequently by my interviewees. ${ }^{64}$ These increased pressures led many women to fear for the continued provision of "a humane service". ${ }^{55}$ Doctors at Cook's hospital were instructed to see more patients, whilst spending less time with each. Carol (b.1948), a social worker, experienced similar demands in the early 1990s. Carol worked in the child protection aspect of social work, doing pre-birth risk assessments in hospitals. It was a difficult and stressful job because "a lot of it was drug related and domestic violence" and there was great deal of responsibility involved ${ }^{66} \mathrm{Carol}$ did not get on very well with her manager who saw no issue with repeatedly increasing her caseload:

21 My manager hadn't given me a supervision for three months and she told me to take another case and I said I can't I've got too much work already and she said 'Oh it'll only take a week' and it turned into a really nasty case...and I thought I can't do this anymore. I was going around crying all the time. I had terrible headaches and I wasn't sleeping so I did go off with stress, and I was very angry with my manager because she didn't protect me. ${ }^{67}$

Although she was signed off with stress for three months, Carol returned to work within a month because she felt a lot of guilt about being away from her casework. Cook also noted that health workers retained "good will" towards the NHS and therefore "bore the burden of trying to maintain standards in face of constant erosion of support and finance". ${ }^{68}$

23 Managerialism created an especially difficult environment for female workers. Social policy scholars argued in the early 1990s that the introduction of managerialism by Conservative governments into the welfare state should be viewed as "a new set of male power relations located within a performance oriented culture". ${ }^{69}$ Mike Savage has highlighted that the expansion of management that took place in the wake of the reviews had "the most adverse effects on women workers" because it placed many of them even further into a position of powerlessness in the institutional structure..$^{70}$ It is notable that the Working for Patients white paper outlined a system whereby consultants were encouraged to have a role in their own management, and to self-manage as far as possible, but this was not recommended for the overwhelmingly female nursing staff. ${ }^{71}$ In 1992 only 37\% of managers in the public sector were women despite being in the majority of all workers. ${ }^{72}$ Two of my interviewees Rita (b.1952) and Sylvia were promoted to management positions in academia around the mid-1990s. Rita had a difficult experience, given only a temporary contract and feeling that she was often ignored or talked over in meetings and male peers got different treatment even if voicing a similar issue. ${ }^{73}$ She was also under a lot of pressure to recruit international students to bring revenue to the institution even if they did not meet entry requirements; her professional decisions were often overridden by more senior managers. Sylvia had a better experience as manager, but she too expressed frustration at the creep of economization and the expectations from above that students be treated as "consumers". ${ }^{74}$ 


\section{Autonomy}

primary and secondary schooling noted that they had previously enjoyed the autonomy that was given to them to "decide what you wanted to do in the classroom" and to be "creative" in adapting their teaching to the needs of different pupils. ${ }^{78}$ Social policy scholars have argued that during the 1970s, linked to the influence of new social movements such as feminism, there was an increasing emphasis on the subjective judgement of the teacher and the centring of personal experience. It was one of the explicit aims of the Conservative reforms of the late 1980s to marginalize this in the practice of education and the welfare state more broadly, for they thought teachers were choosing (wrongly) to spend time on pupil development "above measurable attainment" ${ }^{79}$

The focus on results and performance across the welfare state, led women to feel as though the centrality of the patient, or the student, or the citizen was being forgotten and replaced by abstractions. Cynthia (b.1941) decided to leave primary teaching in the late 1980s because she was "becoming disenchanted with teaching, like all professions it's become too obsessed with results". ${ }^{80}$ When she returned to work in the mid-1990s "in the hospital as a secretary and the same happened there, it was statistics, you know, you had to prove your worth, so you had to bring all these stats- never mind the clients!" ${ }^{11}$ Ann (b.1939) similarly felt uncomfortable with having to spend time producing stats and making cost-calculations about healthcare provision in her role as PA to a hospital consultant. She felt it violated her belief in healthcare according to need: "I think if you're urgent, you're urgent"..$^{82}$ The performance of the welfare state had always been measured and assessed, but often in different ways to those outlined by the Thatcher and Major governments; measurements were not always statistical, and outcomes were expected over a longer period of time. This is striking when comparing the white paper Better 
Schools with the 1968 survey of the education system All Our Future. The latter features voices of students and the meaning of results is problematized rather than taken as objective truth of ability (of either pupils or teachers). ${ }^{83}$

In order to achieve the results desired by neoliberal governments, welfare professionals lost some of the autonomy to exercise their judgement in their workinglives. Jean was forthright in her opinion that reorganisation of the NHS in the late 1980s had "deskilled" nurses, she explained that it became: "formulaic about what you had to do, how many patients you were seeing and for how long" ${ }^{84}$ She didn't think this was good for patients because you often had to "cut corners like mad" to get everything done and produce all the paperwork to prove that you had stuck to the given timetable. ${ }^{85}$ The terminology of "deskilling" and "box-ticking" also emerged in interviews with female further education lecturers in the mid-1990s. ${ }^{86}$ The interviewer argued this was because "control over the conception and design of academic work is increasingly being taken away, by management, from practitioners responsible for its delivery in the classroom". ${ }^{87}$ Reflections on changes in teaching after the 1988 Education Act (and as it intensified throughout the 1990s) echo the kind of "formulaic" shifts described occurring in the NHS and furthereducation. Teachers found the successive introduction of the national curriculum and SATs was increasingly restrictive; one interviewee described it as "literally a different job ". ${ }^{88}$ Alice stated that "the testing system means everyone has to do exactly the same thing". ${ }^{89}$ Similarly, Maureen noted "it got to the point where you had a booklet for maths, week one day one you do this- some children didn't understand it, sorry we're moving on. And you have to write it up, all these sheets to fill in"..$^{90}$ This encapsulates a central theme of deprofessionalization, the idea that the welfare worker should not be allowed to make judgements on a case-by-case basis but instead actions should conform to a standardised knowable and measurable regime with each moment accounted for.

There was also a marked increase in inspections and observations in schools, linked to but not exactly consonant with the broader culture of managerialism, which was especially stressful for teachers. Teachers had been highlighted by the Thatcher government as an area of particular concern, noting that: "a significant number of teachers are performing at a standard below that required to reach the new objectives". ${ }^{91}$ They therefore advocated a "regular and formal appraisal of the performance of all teachers" which could lead to 'early retirement or dismissal' if unsatisfactory. ${ }^{92}$ The Major government strengthened these provisions by creating OFSTED in 1992 and then introducing the Schools Inspection Act in 1996. Maureen recalled 1996 as an especially difficult year because it was the first inspection she experienced under the new regime. She and her colleagues found the whole process overwhelming:

people started having nervous breakdowns...we had to write policies for every area because we didn't know what we were going to be tested on...a lot of people were off sick with stress, early retirement, even relationship problems, you know, full time teaching plus stressful meetings and demands to write policies- all your spare time..$^{93}$

32 This is reminiscent of Michel Foucault's image of the Panopticon in Discipline and Punish where individuals are controlled through exposure to the gaze of the observer: the possibility of being watched at any given moment "assures the automatic functioning of power". ${ }^{94}$ This worked literally though the inspection system in schools, and through the exponential increase in management figures across the sector, but also more figuratively through the standardisation of tasks. De-professionalization was an important element of the Conservative governments' nascent "regulatory state" which 
constituted "a more complex pattern of government activity...more inspection and regulationeven if less public provision". ${ }^{95}$

\section{Downward Mobility} face of the stress and precarity caused by the increased workload, more monitoring, and fewer resources. This reduction in conditions can be viewed as a form of downwards occupational mobility even if they stayed in the same employment and meant the risk of moving jobs often felt worth taking. India (b.1947) moved from secondary school teaching to the extra-mural department of a university in the late 1980s. India initially had a lot of flexibility to create her own courses which she chose to make inter-disciplinary and "woman-centred". ${ }^{97}$ However she noted that the department "became obsessed by accreditation in the nineties, I had to fit into a module system to degree level". ${ }^{98}$ This meant that much of her course content was marginalized and deemed inappropriate for progression to degree level study. Feeling that what she had to offer was no longer of value to the department, India left in the mid-1990s to pursue freelance teaching which placed her in a precarious financial situation. ${ }^{99}$ Further and adult education had been relatively protected under Thatcher, but there was a significant amount of restructuring and redundancies in the wake of the 1992 Further and Higher Education Act. Growth in health and education employment had slowed in the 1980s and the early-to-mid 1990s witnessed an overall contraction in the number of state workers. ${ }^{100}$ Jean decided to leave nursing around this time because she felt it had become untenable. She had already been a representative on a committee about stress amongst NHS staff because "they wanted my opinion about why they were losing so many nurses through stress". ${ }^{101}$ Jean went on to teach nursing in a further education college but took early retirement to avoid redundancy.

Having to alter career path left many women taking on positions of a lower social status, which could be especially difficult for women who had grown up working-class. After Sandra was made redundant from her position in the regional health authority, she took a role "in the health service, rehousing the mentally ill from a big psychiatric hospital ". However, this was another consequence of NHS reorganization which she did "not approve of- it was the idea of mov[ing] people to the community which meant you could hide them". ${ }^{102}$ Sandra was so uncomfortable with the approach that she decided to leave the sector to start a café with her husband in the mid-1990s. She lamented that as an older woman she was having to spend hours on her feet every day doing fairly menial labour, and worrying financially especially through autumn and winter. ${ }^{103}$ Sandra felt a "failure " that she had ended her career in a non-professional job. ${ }^{104}$ Ruth (b.1949) echoed this sentiment, describing that being made redundant "felt like a horrible inevitability, that you can't really escape your background". ${ }^{105}$

Revue Française de Civilisation Britannique, XXIII-1 | 2018 
36 A number of women have taken up voluntary work in their sectors of previous employment. ${ }^{106}$ However these women are not satisfied with these arrangements; it does not provide them with status in the way paid work did. One of the aims of decreasing public services in the late 1980 s was to reinvigorate civil society and family life because Thatcherite politicians believed caring should be the responsibility of women but largely (and ideally) in a domestic or voluntary setting rather than under the remit of the state ${ }^{107}$ Rita, a university lecturer, was made redundant after a newlyappointed male boss brought in a management consultant. Unable to find another professional role, in the years since she has organised writing workshops for various charities, and volunteered as a counsellor for women with mental health problems. She has also taken on additional caring responsibilities within the family. Rita explained that she felt losing her job reduced her status in society:

After doing something that allowed you to gain expertise and be a player out there in the world, what's expected of you and available to you now is just to do caring way below your skillset without power or status. What you brought to the professions as a female was at least recognised and remunerated in a male world, you weren't a housewife, but now it just feels like being put back in my box. ${ }^{108}$

Even though many women disagreed with the changes and suffered in their careers as a result of them, they often blamed themselves for not being adaptable enough. Despite the fact Maureen felt that the process of de-professionalization had "undermined teachers' authority" she took the position in her interview that teachers themselves need to take responsibility if they cannot handle the increased pressure: "you either do it, you have a breakdown, or you think 'I'm going'. And you get out because you know you can't do what is demanded". ${ }^{109}$ Maureen found herself in the latter position, feeling that she was just no longer up for the job- as did many of my interviewees- and she took early retirement as soon as she was able in the early 2000s. Anita (b.1952), who was made redundant from her job in the public sector due to funding cuts, expressed this selfblame even more emphatically. The issue of her losing her job was woven like a connecting thread throughout the interview. Her statement in the closing moments, when we discussed her continued search for work, is particularly poignant: "I want to be out getting on, I want to make change happen. It's hard to know how to do it, so I'm trying to change myself rather than the outside world, but that's not easy". ${ }^{110}$ This is very much in line with the idea of the neoliberal worker who, as Valerie Walkerdine suggests, "is totally responsible for their own destiny, and so techniques and technologies of regulation focus on the self-management of citizens to produce themselves as having the skills and qualities necessary to succeed in the new economy". ${ }^{111}$

\section{Conclusion}

Between 1987 and c.1997 a rapid process of de-professionalization was engendered in the welfare state by Conservative governments which involved a devaluation of professional expertise, the introduction of a culture of managerialism and a loss of autonomy for workers. Unlike de-industrialization which has impacted male workers, the process of de-professionalization outlined here has disproportionately affected women because of their majority in the public sector and specifically in the semiprofessions within health, welfare and education. Women of the post-war generation employed in these areas experienced fundamental changes in their working-lives, 
which often led to a feeling of loss of status and power in the workplace and society more broadly. Many found themselves unexpectedly downwardly mobile at a crucial stage of their career; either through the reduction in conditions, or through moving or losing a job due to changing conditions. These women grew up during a time when opportunities were expanding for women but they were not immune to the negative effects of structural change in public sector employment. The material presented here suggests that examining later life stages in personal testimony sources can complicate dominant narratives about the collective experience of a generation. Women's life histories are in fact much more likely to be a contradictory narrative of progress and retrenchment because patriarchy is so adaptable. The way patriarchy is enacted changes across time and interacts with contemporary political ideologies; it should be analysed as an historically specific rather than universal concept. The form and impact of de-professionalization demonstrates the dialectic between patriarchy and neoliberalism during this period. De-professionalization deserves to be considered as one of the key explanatory processes of late twentieth-century Britain.

\section{BIBLIOGRAPHY}

Abrams, Lynn, 'Liberating the Female Self: Epiphanies, Conflict and Coherence in the Life Stories of Post-war British Women', Social History, 39 (2014), pp. 14-35.

Arnot, Madeleine, David, Miriam and Weiner, Gaby (eds.), Closing the Gender Gap: Postwar Education and Social Change (Cambridge, Polity Press, 1999).

Brown, Wendy Undoing the Demos: Neoliberalism's Stealth Revolution (New York, Zone Books, 2015).

Cook, Margaret, A Slight and Delicate Creature: The Memoirs of Margaret Cook (London, Orion, 1999).

Cribb, Jonathan, Disney Richard and Sibieta, Richard, The Public Sector Workforce: Past, Present and Future (Institute for Fiscal Studies, 2014).

Cutler, Tony and Waine, Becky, 'Managerialism Reformed? New Labour and Public Sector Management', Social Policy and Administration, 34 (2000), pp. 318-332.

Dale, Jennifer and Foster, Peggy, Feminists and State Welfare (Leicester, Routledge, 1986).

Davis, Angela, 'Uncovering the Lives of Women in Postwar Oxfordshire: An Oral History

Approach', Rural History, 19 (2008), pp. 105-121.

Department of Education, Better Schools, Cmnd 9469, (London, The Stationery Office, 1984).

Department of Health, Working for Patients, CM555 (London, The Stationery Office, 1989).

Douglas, J., Ross, J., Simpson H., All Our Future: A Longitudinal Study of Secondary Education (London, P. Davies, 1968). 
Evans, Eric, Thatcher and Thatcherism (London, Routledge, 2004).

Foucault, Michel, Discipline and Punish: The Birth of the Prison (London, Penguin, 1991).

Gildea, Robert, Mark, James and Waring, Anette (eds.), Europe's 1968: Voices of Revolt (Oxford, Oxford University Press, 2013).

Gillard, D., Education in England: A Brief History (2011), <www.educationengland.org.uk/history> [consulted 22 February 2017].

Glennerster, Howard, British Social Policy since 1945 (Oxford, Blackwell, 2000)

Gordon, Linda (ed.), Women, the State and Welfare (Madison, University of Wisconsin Press, 1990).

Hadley, Louisa and Ho, Elizabeth (eds.), Thatcher and After: Margaret Thatcher and Her Afterlife in Contemporary Culture (Basingstoke, Palgrave MacMillan, 2010).

Hilton Matthew, 'Politics is Ordinary: Non-governmental Organizations and Political Participation in Contemporary Britain', Twentieth Century British History, 22 (2011), pp. 230-268.

Kelsall, R., Women and Teaching: Report on an Independent Nuffield Survey Following Up a Large National Sample of Women Who Entered Teaching in England at Various Dates Pre-War and Post-War (London, The Stationery Office, 1963).

Langhamer, Claire, 'Feelings, Women and Work in the Long 1950s', Women's History Review, 26 (2017), pp. 77-92.

Leathwood, Carole, 'Treat me as a human being- don't look at me as a woman: Femininities and Professional Identities in Further Education', Gender and Education, 17 (2005), pp. 387-409.

Lowe, Rodney, The Welfare State in Britain since 1945 (Basingstoke, Macmillan, 2005)

Mass Observation Archive, University of Sussex, Spring 2004 Directive, W1813.

Mort, Frank, 'Social and Symbolic Fathers and Sons in Postwar Britain', Journal of British Studies, 38 (1999), pp. 353-384.

Parry, Richard, United Kingdom Public Employment: Patterns of Change 1951-1976 (Glasgow, Centre for the Study of Public Policy at University of Strathclyde, 1980).

Perkin, Harold, The Rise of Professional Society: England since 1880, (London, Routledge, 2002).

Philips, Anne and Taylor, Barbara, 'Sex and Skill: Notes Towards a Feminist Economics', Feminist Review, 6 (1980), pp. 79-88.

Rogaly, Ben and Taylor, Becky, Moving Histories of Class and Community: Identity, Place and Belonging in Contemporary England (Basingstoke, Palgrave Macmillan, 2009).

Roper, Michael, Masculinity and the British Organization Man since 1945 (Oxford, Oxford University Press, 1994).

Savage, Mike, 'Affluence and Social Change in the Making of Technocratic Middle-Class Identities: Britain 1939-1955', Contemporary British History, 22 (2008), pp. 457-476.

Savage, Mike, Barlow, James, Dickens, Peter and Fielding, Tony, Property, Bureaucracy and Culture: Middle-Class Formation in Contemporary Britain (London, Routledge, 1992).

Todd, Selina, The People: The Rise and Fall of the Working-Class 1910-2010 (London, John Murray, 2014).

Tomlinson, Jim, ‘De-Industrialization Not Decline: A New Meta-Narrative for Post-War British History', Twentieth Century British History, 27 (2016), pp. 76-99. 
Walkerdine, Valerie, 'Reclassifying Upward Mobility: Femininity and the Neo-Liberal Subject', Gender and Education, 15 (2003), pp. 237-248.

Webster, Wendy, Imagining Home: Gender, 'Race' and National Identity 1945- 64, (London, UCL Press, 1998).

Wilding, Paul, ‘The Welfare State and the Conservatives', Political Studies, XLV (1997), pp. 716-726.

Wilson, Elizabeth, Women and the Welfare State (London, Tavistock, 1977)

Worth, Eve, Women of the Welfare State Generation, c.1945-2015, Oral History Interviews, Held by interviewer Eve Worth.

\section{NOTES}

1. Lynn Abrams, 'Liberating the Female Self: Epiphanies, Conflict and Coherence in the Life Stories of Post-war British Women', Social History, 39 (2014), p. 18

2. Abrams, 'Liberating the Female Self', p. 35

3. Jim Tomlinson, 'De-Industrialization Not Decline: A New Meta-Narrative for Post-War British History', Twentieth Century British History, 27 (2016), pp. 76-99

4. Abrams, 'Liberating the Female Self', p. 16

5. Angela Davis, 'Uncovering the Lives of Women in Postwar Oxfordshire: An Oral History Approach', Rural History, 19 (2008), p. 108.

6. See for example Selina Todd, The People: The Rise and Fall of the Working-Class 1910-2010 (London, John Murray, 2014).

7. Robert Gildea, James Mark and Anette Waring (eds.), Europe's 1968: Voices of Revolt (Oxford, Oxford University Press, 2013).

8. Wendy Webster, Imagining Home: Gender, 'Race' and National Identity 1945- 64, (London, UCL Press, 1998), p. xxii.

9. Howard Glennerster, British Social Policy since 1945 (Oxford, Blackwell, 2000), p. 176.

10. D. Gillard, Education in England: A Brief History (2011), www.educationengland.org.uk/history, last consulted 22 February 2017.

11. Department of Health, Working for Patients, CM555 (London, The Stationery Office, 1989), p. 100.

12. Further key acts include: Local Government Act 1988, Social Security Act 1989, Education Act 1992, Education Act 1993.

13. Wendy Brown, Undoing the Demos: Neoliberalism's Stealth Revolution (New York, Zone Books, 2015), pp. 30-31.

14. Department of Health, Working for Patients, p. 19.

15. Ben Rogaly and Becky Taylor, Moving Histories of Class and Community: Identity, Place and Belonging in Contemporary England (Basingstoke, Palgrave Macmillan, 2009).

16. Tony Cutler and Becky Waine, 'Managerialism Reformed? New Labour and Public Sector Management', Social Policy and Administration, 34 (2000), pp. 318-332.

17. Harold, Perkin, The Rise of Professional Society: England since 1880, (London, Routledge, 2002), pp. 2-3.

18. Ibid.

19. Richard Parry, United Kingdom Public Employment: Patterns of Change 1951-1976 (Glasgow, Centre for the Study of Public Policy at University of Strathclyde, 1980), p.8 Parry notes that by 1976 a higher percentage of the public sector workforce was female than in private sector, p. 34 .

20. Ibid., p. 1.

21. Ibid., p. 34 
22. Madeleine Arnot, Miriam David and Gaby Weiner (eds.), Closing the Gender Gap: Postwar Education and Social Change (Cambridge, Polity Press, 1999), pp. 58-59.

23. Interview with Jean, $13^{\text {th }}$ April 2015 (All interviewee names are pseudonyms).

24. R. Kelsall, Women and Teaching: Report on an Independent Nuffield Survey Following Up a Large National Sample of Women Who Entered Teaching in England at Various Dates Pre-War and Post-War (London, The Stationery Office, 1963), p. 24.

25. Interview with Sylvia, $18^{\text {th }}$ April 2015.

26. Michael Roper, Masculinity and the British Organization Man since 1945 (Oxford, Oxford University Press, 1994), pp. 1-15.

27. Linda Gordon (ed.), Women, the State and Welfare (Madison, University of Wisconsin Press, 1990), p.18

28. Elizabeth Wilson, Women and the Welfare State (London, Tavistock, 1977).

29. Jennifer Dale and Peggy Foster, Feminists and State Welfare (Leicester, Routledge, 1986) pp. 81-104.

30. Jonathan Cribb, Richard Disney and Luke Sibieta, The Public Sector Workforce: Past, Present and Future, (Institute for Fiscal Studies, 2014), p. 17.

31. Rodney Lowe, The Welfare State in Britain since 1945 (Basingstoke, Macmillan, 2005), p. 331.

32. Mike Savage, James Barlow, Peter Dickens and Tony Fielding, Property, Bureaucracy and Culture: Middle-Class Formation in Contemporary Britain (London, Routledge, 1992), p. 75.

33. Anne Philips and Barbara Taylor, 'Sex and Skill: Notes Towards a Feminist Economics', Feminist Review, 6 (1980), p. 79.

34. Margaret Thatcher quoted in Louisa Hadley, Elizabeth Ho (eds.), Thatcher and After: Margaret Thatcher and Her Afterlife in Contemporary Culture (Basingstoke, Palgrave MacMillan, 2010), p. 31.

35. Eric Evans, Thatcher and Thatcherism (London, Routledge, 2004), p. 67.

36. Lowe, Welfare State, pp. 330-331.

37. Interview with Elizabeth, $27^{\text {th }}$ January 2015.

38. Interview with Sandra, $17^{\text {th }}$ April 2015.

39. Interview with Maureen, $10^{\text {th }}$ April 2015.

40. Interview with Sandra.

41. Interview with Elizabeth.

42. Interview with Jean.

43. Mass Observation Archive, University of Sussex (MOA), Spring 2004 Directive, W1813.

44. Department of Education, Better Schools, Cmnd 9469, (London, The Stationery Office, 1984), p. 15.

45. MOA, Spring 2004 Directive, W1813.

46. Matthew Hilton, 'Politics is Ordinary: Non-governmental Organizations and Political Participation in Contemporary Britain', Twentieth Century British History, 22 (2011), pp. 252-253.

47. Paul Wilding, 'The Welfare State and the Conservatives', Political Studies, XLV (1997), p. 718.

48. Hilton, 'Politics is Ordinary', pp.252-253 and Mike Savage, 'Affluence and Social Change in the Making of Technocratic Middle-Class Identities: Britain 1939-1955', Contemporary British History, 22 (2008), pp. 457-476.

49. Frank Mort, 'Social and Symbolic Fathers and Sons in Postwar Britain', Journal of British Studies, 38 (1999), pp. 353-384.

50. Roper, Masculinity, p. 1.

51. Ibid., p. 77.

52. Claire Langhamer has explored the false dichotomy between the rational and the emotional in the workplace in, 'Feelings, Women and Work in the Long 1950s', Women's History Review, 26 (2017), pp. 77-92.

53. Department of Health, Working for Patients, p. 20.

54. Department of Education, Better Schools, p. 44. 
55. Ibid., p. 7.

56. Margaret Cook, A Slight and Delicate Creature: The Memoirs of Margaret Cook (London, Orion, 1999), p.188

57. Lowe, Welfare State, p. 333.

58. Department of Health, Working for Patients, p. 61.

59. Savage et al., Property, pp. 74-75.

60. Interview with Lois, $4^{\text {th }}$ September 2014.

61. Cook, Slight, p. 188.

62. Interview with Barbara, $5^{\text {th }}$ December 2014.

63. Interview with Barbara.

64. Interviews with Ann, $4^{\text {th }}$ February 2015, Dawn, $12^{\text {th }}$ September 2014.

65. Cook, Slight, p. 188.

66. Interview with Carol, $17^{\text {th }}$ November 2014.

67. Ibid.

68. Cook, Slight, p. 189.

69. Arnot, Closing the Gender Gap, p. 99.

70. Savage et al., Property, p. 76.

71. Department of Health, Working for Patients, pp. 15-19.

72. Savage et al., Property, p. 197.

73. Interview with Rita, $20^{\text {th }}$ October 2015.

74. Interview with Sylvia.

75. Interview with Rita.

76. Interview with Jean.

77. Interview with Carol.

78. Interviews with Maureen, Cynthia.

79. Arnot, Closing the Gender Gap, pp. 94-97.

80. Interview with Cynthia.

81. Ibid.

82. Interview with Ann.

83. J. Douglas, J. Ross, H. Simpson, All Our Future: A Longitudinal Study of Secondary Education (London, P. Davies, 1968), Department of Education, Better Schools.

84. Interview with Jean.

85. Ibid.

86. Carole Leathwood, 'Treat me as a human being- don't look at me as a woman: Femininities and Professional Identities in Further Education', Gender and Education, 17 (2005), p. 398.

87. Ibid., p. 390.

88. Interview with Lesley, $19^{\text {th }}$ July 2015.

89. MOA, Spring 2004 directive, W1813.

90. Interview with Maureen.

91. Department of Education, Better Schools, p. 50.

92. Ibid., p. 55.

93. Interview with Maureen.

94. Michel Foucault, Discipline and Punish: The Birth of the Prison (London, Penguin, 1991), p. 201.

95. Wilding, 'The Welfare State', p. 722.

96. Todd, The People, pp. 322-326.

97. Interview with India, $28^{\text {th }}$ March 2016.

98. Ibid.

99. Ibid.

100. Cribb et al., Public Sector Workforce, p. 12. 
101. Interview with Jean.

102. Interview with Sandra.

103. Ibid.

104. Ibid.

105. Interview with Ruth, $17^{\text {th }}$ October 2015.

106. Interviews with Chrissie, $18^{\text {th }}$ October 2015 , Lois, Sandra, Jean.

107. Glennerster, British Social Policy, pp. 195-197.

108. Ibid.

109. Interview with Maureen.

110. Interview with Anita, $1^{\text {st }}$ February 2015.

111. Valerie Walkerdine, 'Reclassifying Upward Mobility: Femininity and the Neo-Liberal Subject', Gender and Education, 15 (2003), pp. 241-242.

\section{ABSTRACTS}

This article argues that though women born in the long 1940s experienced an expansion in educational and occupational opportunities, these opportunities were largely in gender segregated jobs within the welfare state. These same jobs were hit hard by the depreciation in working-conditions that occurred from the late 1980s onwards. Women of this generation's material circumstances and sense of self were significantly affected by these changes; in part, precisely because they had been socialized to expect more from their working-lives. By foregrounding female experience, the article also aims to demonstrate that the shifts in public sector employment enacted by successive Conservative governments constituted a process of deprofessionalization which principally impacted women workers. This demonstrates the adaptability of gendered inequality. De-professionalization had such profound implications that it deserves to be considered alongside de-industrialization as one of the key explanatory processes of late twentieth-century Britain and the neoliberal project; doing so would mark a shift away from the masculinised narratives of work that dominate contemporary history.

Les femmes nées dans les années 1940 ont vu s'ouvrir devant elles un vaste champ d'opportunités éducatives et professionnelles. Cet article montre que ces opportunités étaient principalement présentes dans de nouveaux métiers très féminisés liés à l'Etat-providence. Ces métiers furent durement touchés à partir des années 1980 par une dégradation marquée des conditions dans lesquelles ils s'effectuaient. La situation matérielle des femmes de cette génération et leur estime de soi en furent atteintes, notamment parce qu'elles avaient intériorisé l'idée qu'elles pouvaient attendre beaucoup de leur vie professionnelle. En mettant l'expérience de ces femmes au premier plan, cet article cherche à démontrer que les réformes répétées de l'emploi dans le secteur public poursuivies par les gouvernements Conservateurs successifs ont constitué un processus de déprofessionnalisation qui impacta principalement des employées. Nous voyons ainsi comment les inégalités de genre s'adaptent à de nouveaux contextes. La dé-professionnalisation a eu des implications si profondes qu'elle mérite d'être considérée, au même titre que la désindustrialisation, comme l'un des processus caractéristiques du projet néolibéral à l'œuvre au Royaume-Uni à la fin du vingtième siècle. Une telle reconnaissance nous éloignerait des discours historiographiques dominants sur le monde du travail, entièrement centrés sur l'expérience professionnelle masculine. 
INDEX

Mots-clés: femmes, Etat providence, dé-professionnalisation, années 1980, histoire orale, travail, néolibéralisme

Keywords: women, welfare state, de-professionalization, 1980s, oral history, work, neoliberalism

\section{AUTHOR}

\section{EVE WORTH}

Jenny Wormald Junior Research Fellow in Women's History, St Hilda's College, University of Oxford 